\title{
MEMBEDAH ANATOMI FIQH SIYĀSAH DALAM PUTUSAN MAHKAMAH KONSTITUSI TENTANG PRESIDENTIAL THRESHOLD
}

\author{
Muhamad Sofi Mubarok \\ Dosen Ușūl al-fiqh IAIN Syekh Nurjati Cirebon \\ e-mail: sofi.mubarok234@gmail.com
}

\begin{abstract}
The Constitutional Court sets presidential threshold as an open legal policy or open law policy for legislators. In other words, presidential threshold as stipulated in Act Number 7 of 2017 on General Elections, especially in the article 222, does not contradict to the Constitution of the Republic of Indonesia 1945 and its accordance with efforts to maintain government stability. Although this decision left two constitutional judges dissenting opinion since it was issued, the decision is relevant to the fiqh siyāsah construct concerning the need to maintain government stability through determining sufficient conditions in the selection process for the head of state. Borrowing Norman Fairclough's Critical Discourse Analysis (CDA) approach, the decision is in accordance to the fiqh siyasah dictum for two reasons. First, there is a religious dogma which states that a head of state must come from the strongest clan through prophet tradition (al-hadis) states, alaimmatu min-quraysyin. Second, in the fiqh siyasah tradition, any policy can be formulated as long as the benefit of the people can be achieved. The stipulation of strict prerequisites is not intended to obstruct the right of a mukallaf to be elected as head of state, but aims to achieve other interests that are greater and benefit society, in the form of advocating for the rights of the state, ensuring a
\end{abstract}


sense of security, and the realization of religious values in social life.

Keywords: Constitutional Court, Figh Siyāasah, Open Legal Policy, Presidential Threshold

\section{Pendahuluan}

Dari sekian tema studi hukum Islam meliputi perdata, ekonomi, praktik keagamaan dan panduan Islam dalam penyelenggaraan pemerintahan, ${ }^{1}$ hukum privat dan perdata masih menjadi topik paling diminati. $^{2}$ Sementara figh siyasab yang membahas tema-tema pemerintahan relatif sulit ditemukan. Temuan Sa'id 'Asymāwi tentang teori politik Islam yang disusun di masa kekuasaan Bani 'Abbasiyah turut memengaruhi perkembangan figh siyasah sebagai sub-tema hukum Islam yang nyaris tak tersentuh karena hegemoni penguasa terhadap ahli hukum saat itu. ${ }^{3}$

Sesungguhnya, upaya menyusun, merumuskan kerangka konseptual, kaidah, serta norma fiqh siyasah telah lama dilakukan. Sebut saja misalnya, karya-karya yang ditulis Abu al-Hasan al-Māwardi (w. 1058), ${ }^{4}$ al-Juwayni (w. 1085) ${ }^{5}$ dan al-Ghazāili (w. 1111), ${ }^{6}$ banyak dirujuk

1 Arskal Salim dan Azyumardi Azra, "Introduction: The State and Sharia in the Perspective of Indonesian Legal Politics", dalam Arskal Salim dan Azyumardi Azra, (ed.), Sharia and Politics in Modern Indonesia (Singapura: Institute of Southeast Asia Studies, 2003), 11. Lihat juga: Samsudin Aziz, "Kanunisasi Fikih Jinayat Kontemporer: Studi Materi Muatan Qanun Jinayat Aceh dan Brunei Darussalam", Al-Ahkam: Jurnal Pemikiran Hukum Islam, Vol. 24, No. 2 (2014), 174.

2 Sami Zubaida, Law and Power in The Islamic World (New York: I.B. Tauris \& Co. Ltd, 2005).

${ }^{3}$ Sa'id Asymawi mengajukan keberatan terhadap fiqh siyasah sebagai sebuah sub-disiplin ilmu fiqh berdasarkan empat hal. Pertama, siyasah atau khilafah dikenal sebagai sistem kekuasaan dan bukan sebagai disiplin ilmu. Untuk dikatakan sebagai sebuah disiplin ilmu, figh siyasah tidak memiliki batasan yang jelas, terukur, kaidah-kaidah pokok hingga cabang disiplin sebagaimana dimiliki disiplin ilmu lainnya. Kedua, adanya tekanan para penguasa terhadap para ulama fiqh, sehingga fiqh siyasab tidak begitu berkembang. Karya al-Māwardi sendiri, al-Aḥkām al-Sulțanniyyah, baru dipublikasikan setelah ia wafat berdasarkan wasiat yang ia buat sendiri. Ketiga, Fiqh siyasab tak lebih merupakan produk peperangan. Keempat, tak ada dialektika keilmuan dalam figh siyasah. Perdebatan akademik tentang teori-teori politik Islam tak ditemukan di masa penyusunannya serta penyusunan teori fiqh siyāsah dibentuk untuk melegitimasi penguasa saat itu. Sa īid 'Asymāwī, al-Khiläfah al-Islämiyyah, vol. II (Kairo: Sina lil-Nasyr, cet. Ke-2, 1992), 233234.

${ }^{4}$ Kitab yang ditulis Al-Māwardi, al-Aḥkām al-Sultāniyyah, merupakan karya paling populer di bidang politik Islam. Karya ini ditulis ke dalam 20 pembahasan dan dua topik utama, yaitu teori politik dan pemerintahan sebagai sebuah negara dalam Islam serta 
sebagai kitab induk politik Islam yang ditulis dengan tradisi Sunni. Dalam memandang hubungan agama dan negara, kalangan Sunni terinspirasi dari pandangan Al-Ghazāil yang menyatakan kekuasaan dan agama sebagai saudara kembar. ${ }^{7}$ Lain halnya dogma dan ritus keagamaan yang bersumber dari wahyu an sich, Ibn 'Aqiil al-Ḥanbali (w. 1119) menekankan basis siyasah pada setiap usaha menghadirkan nilai kemaslahatan dan menolak segala bentuk bahaya bagi manusia. ${ }^{8}$ Ketidakpastian (uncertain) dalam menentukan ruang lingkup figh siyasah inilah yang mengakibatkan penyusunan teori-teori hingga praktik siyasah sering kali terjebak ke dalam konflik kepentingan, bahkan sejak awal munculnya kekuasaan Islam pasca wafatnya Nabi Muhammad Saw.

Teori politik Islam lebih banyak membahas teori-teori kekuasaan dan prasyarat kepemimpinan. Dari tujuh diktum yang diajukan Abu alḤasan al-Māwardi (w. 1058), ${ }^{9}$ satu di antaranya merupakan prasyarat

kaidah-kaidah umum dalam mengatur tata kelola pemerintahan. Penulisan al-Aḥkām alSultāniyyah didasarkan pada pemenuhan kehendak penguasa saat itu yang meminta alMáwardi untuk memetakan konstruk fiqh yang dapat digunakan dalam menyusun kerangka kinerja pemerintah. Karena itulah, al-Aḥkām al-Sulțaniyyah ditulis dengan dua corak mazhab sekaligus, yaitu Hanafiyah dan Syafi'iyah. Selengkapnya, lihat: Muhammad Hazim Ahmad, "Book Review: Ali bin Muhammad Al-Māwardi, 2006, AlAbkam As-Sulthaniyyah, Tahkik: Ahmad Jad, 1 Jilid, 336 halaman,' 'Ulum Islamiyyah: The Malaysian Journal of Islamic Sciences 23 (April, 2018), 115-127.

${ }^{5}$ Karya monumental al-Juwayni di bidang figh siyasah ialah Ghiyath al-Umam.

${ }^{6}$ Nama lengkapnya ialah Abu Hamid Muhammad ibn Muhammad al-Ghazāili, salah satu ahli hukum Islam popular bermazhab Syafi'iyah. Ia banyak menulis di berbagai disiplin keilmuan Islam, mulai dari yurisprudensi hukum Islam (usūul al-fiqh), filsafat hingga mistisisme Islam. Karya monumental yang sering dirujuk dalam studi politik Islam ialah al-Tibr al-Masbuk, fi-Nashihat al-Muluk.

${ }^{7}$ Dalam karya monumentalnya, Al-Imam al-Ghazāili menyatakan kekuasaan atau politik dan agama sebagai saudara kembar tak terpisahkan. Posisi agama sendiri, menurut alGhazāii, merupakan dasar atau pokok (al-ash), sementara kekuasaan merupakan cabang (al-far') yang terpisah dari agama. Idealnya, menurut Al-Ghazāili, posisi ahli hukum Islam harus menjadi penasehat kerajaan agar penyelenggaraan pemerintahan yang dijalankan penguasa tetap berada dalam koridor syariah dalam merealisasikan nilai-nilai agama dan kepentingan umum. Relasi agama dan politik diungkap al-Ghazāi dengan hubungan antara jamaah haji dan pengawalan para jamaah haji agar sampai di tempat tujuannya ke Tanah Suci. Al-Imam al-Ghazāili, Ibya Ulum ad-Din (Beirut: Dār Ibn Hazm, 2006), 2526.

8 Ibn Hazm, al-Ṭuruq al-Hukmiyyah fil-Siyasah al-Syar'iyyah, tahqiq 'Isham Faris alHarastani dan Hisan Abd al-Manan, (Beirut: Dār al-Jil, 1998), 17.

9 Tujuh diktum yang disebutkan al-Māwardi merupakan tujuh kriteria yang harus dimiliki kepala negara, yaitu adil, kapabilitas berijtihad, sehat panca indera, memiliki anggota badan yang sempurna dan tidak cacat, memiliki akal sempurna sehingga dapat mengelola rakyat dan mengatur kemaslahatan, memiliki keberanian sehingga mampu 
Quraisy yang mulai dikenal terutama pasca ditemukan hadis yang berbunyi,

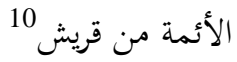

Prasyarat Quraisy inilah yang menjadi basis teori 'asabiyyah Ibn Khaldūn. Ia mengungkap negara membutuhkan 'asabiyyah untuk menjamin stabilitas pemerintahannya. Meski demikian, pernyatan 'asabiyyah tak sepenuhnya diamini sarjanawan Muslim lainnya. Mamduh al-'Araby, misalnya, menyatakan 'asabiyyah bertentangan dengan praktik nabi saat mendirikan Negara Madinah dan menempatkan berbagai komunitas dan agama pada level yang sama. ${ }^{11}$ Narasi 'asabiyyah di satu sisi memperkuat anggapan bahwa ajaran Islam sangat dipengaruhi kultur Arab, di samping narasi misoginis yang terdapat dalam sejumlah teks korpus syariah, relasi orang merdeka dan hamba sahaya, serta distingsi Muslim nonmuslim dalam konteks berbangsa dan bernegara. Namun secara keseluruhan ahli hukum Islam setuju bahwa tujuan dirumuskannya fiqh siyāsah adalah mencapai kemaslahatan umat manusia.

Meski tak secara langsung mengadopsi doktrin fiqh siyasah, putusan Mahkamah Konstitusi ${ }^{12}$ layak dikategorikan dalam studi hukum Islam normatif, ${ }^{13}$ terutama jika dikaitkan dengan adagium yang menyatakan sejumlah prasyarat calon kepala negara yang perlu dihadirkan dalam diktum fiqh siyasah, termasuk prasyarat Quraisy, bertujuan untuk mewujudkan pemerintahan yang stabil. Dalam kapasitas sebagai lembaga negative legislator, ${ }^{14}$ hadirnya putusan $\mathrm{MK}$ tentang ambang batas

melindungi negara dan melawan musuh, serta berasal dari keturunan Quraisy. Abu alḤasan al-Māwardi, al-Aḥkām al-Sultaninyyah (Kuwait: Maktabat Dār Ibn Qutaybah, 1989), 5.

10 Ahmad ibn Muhammad ibn Hanbal, Musnad Imam Aḥmad Ibn Hanbal, Juz II (Beirut: al-Maktabah al-Islāmi, 1398), 421.

There are no sources in the current document.

11 Muhammad Mamduh al-'Araby, Dawlat al-Rasul fil-Madinah (T.t.: al-Hay'ah alMishriyah al-'Ammah lil-Kitab, 1988), 166.

12 Selanjutnya disebut MK.

${ }^{13}$ M. Atho Mudzhar menyatakan, keliru jika pemahaman tentang studi hukum Islam direduksi hanya pada proses istinbath hukum, sehingga ujung dari semua studi Islam bermuara pada upaya menentukan status hukum dalam perspektif hukum Islam. Lebih jauh, Atho Mudzhar menawarkan tiga pandangan seputar wilayah studi hukum Islam kontemporer, yaitu studi filsafat hukum Islam, studi hukum Islam normatif dan studi hukum Islam empiris yang termasuk di dalamnya mencakup studi sosiologi hukum guna menjelaskan pola dan perilaku masyarakat sebagai respons terhadap hukum Islam atau dampak pelaksanaannya. Selengkapnya, lihat: M. Atho Mudzhar, "Tantangan Studi Hukum Islam di Indonesia Dewasa Ini," Indo-Islamika 2, No. 1 (2012/1433), 91-103.

${ }^{14}$ Istilah "negative legislator" diterjemahkan sebagai tindakan MK dalam membatalkan norma melalui judicial review bila bertentangan dengan UUD 1945. Mohammad Fandi 
pencalonan presiden dan wakil presiden (selanjutnya disebut presidential threshold) menarik dianalisis mengingat putusan tersebut menuai kontroversi karena menetapkan presidential threshold merupakan open legal policy pembuat undang-undang dalam mewujudkan pemerintahan yang stabil. Selain itu, MK mendalilkan bahwa ada tidaknya kebijakan presidential threshold tidak bertentangan dengan UUD 1945.

Berdasarkan latar belakang demikian, penulis dapat mengidentifikasi beberapa kata kunci yang ditemukan, yaitu: (1) Legitimasi putusan MK dalam hukum Islam, (2) Open legal policy pembentuk undang-undang; (3)Perlunya menetapkan presidential threshold dalam membangun stabilitas pemerintahan; (4) Relevansi putusan tersebut dengan norma yang terkandung dalam hadis Quraisy guna menghindari konflik dan peperangan antar suku serta terjaminnya pemerintahan yang stabil; (5) Pengajuan syarat calon presiden yang ketat.

Tulisan sederhana ini memfokuskan pada dua masalah utama. Pertama, bagaimana posisi MK dalam konstruk fiqh siyasah. Kedua, menguji putusan MK tentang norma yang lahir dari putusan tersebut, berupa presidential threshold sebagai kebijakan hukum terbuka (open legal policy) menurut figh siyasah. Objek materi tulisan ini adalah Putusan Mahkamah Konstitusi Nomor 48/PUU-IX/2011 dan putusan Nomor 53/PUU$\mathrm{XV} / 2017$. Metode yang digunakan berupa analisis konten (content analysis) dengan pendekatan analisis wacana kritis (Critical Discourse Analysis) yang dikembangkan Norman Fairclough. ${ }^{15}$ Pendekatan tersebut dipilih untuk menguji konsistensi pertimbangan MK melalui dua putusan presidential threshold terhadap transformasi kewenangan MK menuju positif legislator

Denisatria, S.H., "Mahkamah Konstitusi sebagai Negative Legislator dan Positive Legislator," sumber: https://www.hukumonline.com/klinik/detail/ulasan/lt5c062fbc83162/mahkamahkonstitusi-sebagai-inegative-legislator-i-dan-ipositive-legislator-i. Diakses: 09/11/2020, Pkl. 22.12 WIB.

15 Kekuatan metode analisis wacana kritis yang dikembangkan Fairclough, menurut Jorgensen dan Phillips sebagaimana dikutip Elya Munfarida, terletak pada upayanya dalam menyatukan tiga tradisi sekaligus, yaitu analisis tekstual di bidang linguistik, analisis makro-sosiologis dari praktik sosial, dan tradisi interpretatif mikro-sosiologis dalam disiplin ilmu sosiologi. Dengan menyatukan ketiga tradisi tersebut, Fairclough mengkritik analisis an sich terhadap teks seperti yang dilakukan pakar linguistik karena gagal mengungkap konstruk sosio-kultural yang melatarbelakangi lahirnya suatu teks. Selanjutnya, Fairclough juga sekaligus melontarkan kritik tajam terhadap para pengikut post-strukturalis yang lebih menekankan aspek sosio-kultural suatu teks dengan tidak menyediakan metodologi yang cukup memadai bagi analisis teks yang pada dasarnya merupakan representasi dan artikulasi dari pemikiran, kepentingan, dan ideologi yang diinternalisasi ke dalam teks. Elya Munfarida, "Analisis Wacana Kritis dalam Perspektif Norman Fairclough,” Komunika 8, No. 1 (Januari - Juni, 2014), 8. 
dalam menjamin konstitusionalitas norma suatu undang-undang serta upaya melindungi hukum dan rasa keadilan masyarakat. Selain itu, pendekatan fiqh siyasah juga digunakan untuk menganalisis sejauh mana MK konsisten mewujudkan kemaslahatan publik sebagaimana diatur UUD 1945 dalam menyusun putusan.

\section{Menakar Posisi Mahkamah Konstitusi dan Presidential Threshold dalam Perspektif Hukum Islam}

Pertanyaan sering diajukan intelektualis Muslim terkait apakah hukum fikih menjadi satu-satunya produk hukum Islam atau tidak. Shihāb al-Dìn al-Qarāifi ${ }^{16}(626-684$ H/1258 M) mengajukan pendapatnya bahwa wilayah hukum terbagi menjadi tiga domain, yaitu wilayah

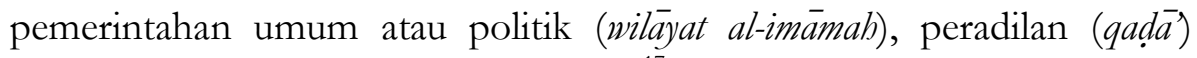
serta wilayah fatwa keagamaan (ifta) $){ }^{17}$ Pandangan demikian tak jauh berbeda dengan argumentasi 'Abd al-Wahhāb Khalāf (1888-1956) tentang tiga domain hukum Islam. ${ }^{18}$

Berangkat dari pernyataan al-Qarā̄ì dan 'Abd al-Wahhāb Khalāf tersebut, MK dapat dikategorikan sebagai lembaga peradilan yang menangani kasus-kasus persengketaan yang dianggap merugikan hak-hak warga negara atau institusi tertentu pasca dirumuskannya suatu undangundang. ${ }^{19} \quad$ Kehadiran lembaga peradilan seperti MK secara khusus

16 Nama lengkapnya adalah Shihāb al-Dīn Abu al-'Abbās Aḥmad ibn Idrīs ibn 'Abdurraḥmān al-Qarāfí, seorang ulama penganut Mazhab Malikiyah kelahiran Mesir. Beliau merupakan salah satu ulama yang sangat produktif melahirkan karya-karya di bidang ușul al-fiqh, hukum Islam dan bidang lain Di antara karya monumentalnya ialah al-Furuq setebal empat jilid, al-Iḥkam, serta karya jenius lainnya. Khairuddin ibn Mahmūud al-Zirkili, al-A'lām, cet. Ke-15, vol. 1 (Tt: Dār al-'Ilm lil Malāyin, 2002), 94-95. ${ }_{17}$ Al-Qarāfi menilai, masing-masing wilayah tersebut memiliki karakteristik penggalian hukum yang berbeda antara satu dan lainnya. Seperti kewenangan kepala negara yang berhak mengatur urusan ketatanegaraan, serta keharusan seorang hakim memiliki daya analisis tajam dalam mempertimbangkan aspek maslahat-mafsadat serta melerai dua

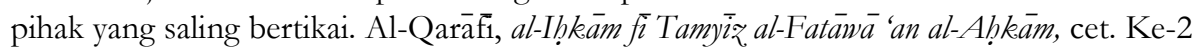
(Beirut: Dār al-Bashāir al-Islāmiyyah, 1995), 46-53.

18 'Abd al-Wahhāb Khalāf, al-Sulthat al-Thalath fi al-Islam, cet. Ke-2 (Kuwait: Dār alQalam, 1985).

${ }_{19}$ Salah satu kewenangan yang dimiliki Mahkamah Konstitusi ialah menguji undangundang terhadap Undang-undang Dasar Republik Indonesia (UUD RI) Tahun 1945Pasal 24C ayat 1 UUD 1945 yang ditegaskan kembali dalam Pasal 10 ayat 1 huruf a sampai dengan d UU 24/2003 tentang Kewenangan Mahkamah Konstitusi. Kewenangan ini, juga mengandung arti bahwa wewenang untuk menyelesaikan persoalan perundang-undangan yang dianggap berpotensi merugikan warga negara. Syafran Sofyan, "Putusan Mahkamah Konstitusi Tentang Status Anak Luar Kawin", www.jimlyschool.com (diakses 21/02/2014). 
diapresiasi Wahbah al-Zuhayli sebagai terobosan agama untuk melakukan pengawasan terhadap kinerja para pejabat struktural pemerintahan serta menjaga stabilitas hukum yang berasas keadilan. Dalam figh siyasah, lembaga peradilan inilah yang kemudian dikenal dengan istilah wilayat almazătim. ${ }^{20}$

Persoalannya, ketiga intelektualis muslim tersebut masih 'terperangkap' dalam kerangka fiqh-oriented, di mana hukum harus digali secara langsung dari teks-teks syariah serta pentingnya menguasai syarat ijtihad. $^{21}$ Seorang hakim di wilayah peradilan ( $q a \bar{d} \bar{a}$ ), misalnya, tetap dituntut memahami berbagai disiplin keilmuan Islam agar hukum yang dihasilkan tetap berada dalam koridor syariah. Teori tersebut jelas tak sesuai dengan fakta penerapan sistem peradilan di beberapa negara, termasuk Indonesia, lantaran peradilan konvensional mengacu pada undang-undang. ${ }^{22}$ Sistem perundang-undangan konvensional tidak mengenal ketentuan yang menyatakan seorang hakim konvensional dituntut menguasai piranti ijtihad hukum Islam. ${ }^{23}$

${ }^{20}$ Wahbah al-Zuhayli, al-Fiqh al-Islämī wa Adillatubū, cet. Ke-12, vol. 8 (Damaskus: Dār al-Fikr, tth), 366. Lihat juga: Fikih Progresif..., vol. 2, 1316.

21 Teks-teks syariah yang dimaksud ialah Al-Qur'an dan hadis. Al-Ghazāili mengisyaratkan Al-Qur'an dan hadis sebatas entitas yang berpotensi melahirkan hukum-hukum (muthmir al-ḥukm). Al-Ghazāili, al-Mustasfá min Tlm al-Ușül, vol. 1 (Beirut: Muassasat al-Risālah, 1997), 148. Namun tak ada kata sepakat di kalangan ulama, apakah Al-Qur'an dan hadis dapat dijadikan dasar atau argumentasi hukum secara langsung atau tidak. Ahli fikih berpendapat, ijtihad tak mungkin diterapkan secara langsung pada teks. Oleh karena itulah seorang mujtahid perlu menguasai perangkatperangkat metodologi lainnya guna membantu proses pengambilan hukum dan menangkap pesan-pesan syariah. Perangkat ijtihad itulah yang disebut dengan usül alfiqh, atau yurisprudensi hukum Islam. Mohammad Hashim Kamali, "Issues in the Legal Theory of Usul and Prospects for Reform", Journal of Islamic Studies,Vol. 40, No. 1 (2001), 5 .

22 Dalam praktiknya, Indonesia menganut dua sistem hukum sekaligus, yaitu hukum Eropa Kontinental (civil law) dan Anglo Saxon (common law). Dalam menyusun peraturan perundang-undangan, Indonesia menempatkan konstitusi dalam urutan tertinggi dari hierarki peraturan perundang-undangan, namun di satu sisi praktik hukum acara di pengadilan menempatkan yurisprudensi sebagai acuan hakim dalam memutus perkara di pengadilan. Lihat: Fajar Nurhardianto, Sistem Hukum dan Posisi Hukum Indonesia," Jurnal TAPIs 11, No. 1 (2015), 34.

23 Muhamad Khalid Mas'ud menilai, di kalangan muslim sendiri terjadi perdebatan cukup sengit terkait apakah seorang hakim dituntut menguasai piranti ijtihad atau tidak. Dalam Konferensi internasional di Leiden yang diselenggarakan International Institute for The Studi of Islam in the Modern World (ISIM) bekerjasama dengan Universitas Amsterdam dan Cornell University 26-28 Oktober 2001 tentang penerapan hukum Islam dalam peradilan, Khalid Mas'ud menyimpulkan bahwa seorang hakim tidak dituntut menguasai piranti ijtihad sebagaimana disyaratkan di dalam disiplin ilmu fikih. Hal tersebut disebabkan hakim di masa sekarang memiliki beban yang sangat besar untuk 
Peliknya persoalan hakim yang harus menguasai perangkat ijtihad tidak pernah menjadi konsensus di kalangan ahli hukum Islam sendiri. Meski belum ada keterangan lebih jauh dalam literatur sejarah Islam terkait putusan-putusan hakim yang berseberangan dengan pendapat fuqaha $\bar{a},{ }^{24}$ secara teoretis Al-Qarā $\bar{f}$ berpendapat, seorang hakim atau qä $\bar{c} \bar{i}$ dituntut memiliki analisis tajam dalam mempertimbangkan aspek maslahat-mafsadat dibandingkan dalil-dalil syariah. ${ }^{25}$ Pendapat ini dipertegas oleh pandangan 'Ali Jum'ah yang menyebutkan seorang hakim yang memiliki pemahaman yang baik terhadap realita dapat mengubah produk-produk fiqh maupun fatwa keagamaan. Sehingga, hakim dapat melakukan terobosan hukum baru dan tidak hanya merujuk pada teks semata seperti yang dilakukan mujtahid fiqh. ${ }^{26}$

Perumusan hukum baru sebagai kelanjutan upaya meneguhkan prinsip keadilan dan hukum juga terlihat pada upaya MK pasca dikeluarkannya Putusan Mahkamah Konstitusi Nomor 48/PUUIX/2011. Putusan tersebut menggeser kewenangan MK dari semula hanya berwenang membatalkan norma undang-undang bila bertentangan dengan UUD 1945 menuju positif legislator untuk menjamin konstitusionalitas suatu norma undang-undang, mengisi kekosongan hukum serta melaksanakan kewajiban hakim dalam menggali, mengikuti dan memahami nilai-nilai hukum dan rasa keadilan yang hidup di tengah masyarakat. Ketentuan tersebut dimuat dalam Undang-Undang Nomor 8 Tahun 2011 tentang Perubahan Atas Undang-Undang Nomor 24 Tahun

menegosiasikan trilogi dikhotomi [syariah, penguasa dan publik] yang sering kali berbenturan satu sama lain. Selain itu, konstitusi di berbagai negara tidak mengadopsi syariah pasca terbentuknya nation-state (negara bangsa) yang berdampak pada diterapkannya undang-undang sekular, termaasuk beberapa negara mayoritas muslim. Oleh karenanya, keringanan diberikan kepada seorang hakim guna menjembatani terdistorsinya syariah dari kepentingan penguasa serta kepentingan publik yang menuntut pelaksanaan Hak Asasi Manusia (HAM) internasional di berbagai bidang. Muhammad Khalid Mas'ud, "Application of Islamic Law in Courts", ISIM, Vol. 9, No. 2 (2006), 5.

${ }^{24}$ Khalid Mas'ud mengungkap, selama periode abad ke-9 hingga 16, hampir dipastikan tidak ada catatan mengenai dokumentasi kehakiman selain dokumen Haram al-Sharif dan rekaman putusan-putusan pengadilan dari sumber tertulis. Keabsahan hukum yang dikeluarkan oleh seorang hakim hanya terbatas pada kasus-kasus spesifik dan tidak bisa menjadi rujukan perundang-undangan oleh para ahli fikih. Dari sinilah kemudian putusan hukum seorang hakim jarang sekali ditulis oleh para ahli fikih dan sering kali mendapat kritikan tajam, sementara di satu sisi ahli fikih hanya terfokus pada upaya membangun teori-teori peundang-undangan (usül al-figh) tanpa mempertimbangkan fakta-fakta kasus partikular. Muhammad Khalid Mas'ud, “Application...": 5.

25 Al-Qarā̄i, al-Iḅkēam..., 53.

26 'Ali Jum'ah, Ilm Ușū al-fiqh wa 'Alāqatubū bil-Falsafah al-Islämiyyah (Kairo: al-Ma'had al-'̄Alami lil-Fikr al-Islāmi, 1996), 34. 
2003 tentang Mahkamah Konstitusi, terutama Pasal 57 ayat (2a) yang mempertegas batasan mengenai putusan yang dapat diambil oleh MK. Selanjutnya, Pasal Pasal 57 ayat (1) dan (2) membatasi kewenangan MK hanya dalam konteks membatalkan undang-undang dan tidak membuat norma baru lantaran kewenangannya dimiliki DPR bersama Presiden/Pemerintah. ${ }^{27}$

Dalam kekuasaan kehakiman, MK dibentuk guna melindungi Hak Asasi Manusia (HAM), hak konstitusional warga negara sekaligus pelindung demokrasi. ${ }^{28}$ Cristof Heyns menekankan, kehadiran MK bertujuan untuk mengurai konflik konstitusionalisasi hak-hak fundamental masyarakat (meliputi Hak Asasi Manusia, sosial, ekonomi dan kebudayaan) dan undang-undang yang terlanjur berlaku. ${ }^{29}$ Putusan MK diproyeksikan guna merealisasikan asas keadilan dan kepastian hukum dengan berpijak pada nilai-nilai kemanusiaan, kemakmuran dan kesejahteraan (welfare state). ${ }^{30}$

Barangkali, hal-hal tersebut yang menjadikan MK memutuskan menolak gugatan judicial review terhadap UU Pemilu, terutama Pasal yang menjelaskan tentang ketentuan presidential threshold. Melalui dua putusannya, yaitu putusan Nomor 53/PUU-XV/2017, MK menyebutkan rumusan Pasal 222 UU Pemilu yang di-judicialreview-kan bertujuan untuk menghindari "presidensial rasa parlementer" dalam posisi presiden yang tidak didukung mayoritas suara di DPR namun ia harus memenuhi janjinya untuk merealisasikan seluruh janjinya saat

\footnotetext{
${ }^{27}$ Selengkapnya, lihat: Undang-Undang Nomor 8 Tahun 2011 tentang Perubahan Atas Undang-Undang Nomor 24 Tahun 2003 tentang Mahkamah Konstitusi.

${ }_{28}$ Terdapat lima (5) fungsi Mahkamah Konstitusi pengawal konstitusi (the Guardian of the constitution), penafsir final konstitusi (the final interpreter of the constitution), pelindung hak asasi manusia (the protector of human rights), pelindung hak konstitutional warga negara (the protector of the citizen's constitutional rights), dan pelindung demokrasi (the protector of democracy), yang dalam kekuasaan kehakiman diimplementasikan dalam empat wewenang dan satu (1) kewajiban. Sesuai ketentuan dalam Pasal 24C UUD 1945, terutama ayat (1) dan (2) meliputi empat wewenang dan satu kewajiban. Wewenang tersebut antara lain menguji undang-undang terhadap Undang-undang Dasar, memutus sengketa kewenangan lembaga negara yang kewenangannya diberikan oleh Undang-undang Dasar, memutus pembubaran partai politik, dan memutus perselisihan tentang hasil pemilihan umum. Sementara kewajiban Mahkamah Konstitusi adalah memberikan putusan atas pendapat DPR mengenai dugaan pelanggaran hukum yang dilakukan oleh Presiden dan/atau Wakil Presiden menurut Undang-Undang Dasar.

${ }^{29}$ Christof Heyns, "Introduction to Socio-Economic Rights in The South African Constitution [Part 1]", 2, t.th, dalam Maruarar Siahaan, "Peran Mahkamah Konstitusi dalam Penegakan Hukum Konstitusi", Jurnal Hukum, Vol. 16, No. 3 (2009), 362.

${ }^{30}$ Khairul Fahmi, "Nilai-nilai Filosofi Putusan Mahkamah Konstitusi yang Final dan Mengikat”, Jurnal Konstitusi, Vol. 7, No. 3 (2010), 114-116.
} 
berkampanye, serta di sisi lain merupakan upaya penyederhanaan partai politik sesuai amanat UUD $1945 .^{31}$

Dalam pertimbangan putusannya, MK mendalilkan hal-hal sebagai berikut. $^{32}$ Pertama, sistem presidensial merupakan skenario constitutional engineering untuk menyederhanakan partai politik dan menciptakan pemerintahan yang balance (seimbang). Dengan tujuan demikian, sangat logis jika presiden dan wakil presiden harus didukung oleh suara mayoritas partai yang mendapat kursi di parlemen.

Kedua, sistem multipartai yang dipraktikkan di Indonesia telah melahirkan corak pemerintahan presidensial rasa parlementer yang menyulitkan presiden merealisasikan kebijakan-kebijakan yang ia susun sepanjang masa kampanye jika tidak didukung partai politik di parlemen. Keadaan demikian hanya bisa direduksi dan diminalisasi jika dibuat suatu mekanisme yang memungkinkan presiden mendapat dukungan suara partai-partai yang memiliki kursi di DPR.

Ketiga, terjadinya konflik kepentingan (conflict of interest) atau manipulasi partai politik pendukung pemerintah sebagaimana didalilkan pemohon, terutama saat hendak disahkannya Rancangan UU 7/2017 tentang Pemilu, terutama Pasal 222 yang menetapkan ambang batas pencalonan presiden dan wakil presiden didukung oleh minimal 20\% partai atau gabungan partai politik yang mendapat kursi di parlemen atau $25 \%$ partai atau gabungan partai politik dari perolehan suara nasional, menyisakan terjadinya walk out dari Partai Gerinda, Partai Demokrat, PAN dan PKS. Dalam konteks demikian, Mahkamah menyatakan dinamika politik tersebut bukan menjadi kewenangan Mahkamah untuk menilai sepanjang proses pembentukan dan tata cara pembentukan undang-undang tersebut tidak bertentangan dengan UU 1945 dan tidak secara otomatis menyatakan muatan atau materi undang-undang yang dihasilkan inkonstitusional.

Keempat, Mahkamah juga menolak dalil yang diajukan pemohon bahwa muatan Pasal 222 UU Nomor 7 Tahun 2017 tentang Pemilu menciptakan diskriminasi dan secara tegas mengebiri hak konstitutional warga negara untuk dapat dicalonkan sebagai presiden. Mahkamah menilai tidak tepat diskriminasi dijadikan dalil dalam gugatan judicial review terhadap Pasal 222 UU 7/2017, mengingat tidak setiap perbedaan perlakuan dapat dikatakan sebagai diskriminasi. Sesuatu dapat dikatakan diskriminasi manakala perbedaan perlakukan tersebut muncul jika semata-mata didasarkan para agama, suku, ras, golongan, status sosial

\footnotetext{
31 Putusan Mahkamah Konstitusi Nomor 53/PUU-XV/2017: 124-130.

32 Selengkapnya, lihat: Putusan Mahkamah Konstitusi Nomor 53/PUU-XV/2017 tentang Pengujian UU Nomor 7 Tahun 2017 tentang Pemilihan Umum.
} 
serta hal lainnya sesuai ketentuan dalam Pasal 1 angka 3 Undang-undang Nomor 39 Tahun 2009 tentang Hak Asasi Manusia.

\section{Anatomi Fiqh Siyāsah dalam Putusan MK}

Perlu diperhatikan, studi fiqh siyasah menjadi sub-kajian dalam fiqh muamalah yang perlu memperhatikan hakikat dan substansinya, bukan sebatas format an sich..$^{33}$ Keberanian melakukan ijtihad perlu ditempuh, setidaknya, untuk mengimplementasikan spirit Al-Qur'an yang secara substantif membuka kemungkinan upaya mendialogkan teks dan realitas. Saat menginventarisir sejumlah ayat Al-Qur'an, 'Abd al-Wahhāb Khalāf membagi teks Al-Qur'an ke dalam dua segmen, yaitu teks tertutup dan teks yang membuka ruang ijtihad. Khusus pada segmen kedua, menurutnya, Al-Qur'an membuka ruang ijtihad secara luas, terutama untuk menggali hukum muamalah lantaran teks yang dituturkan secara global (ijmal) sangat dominan. Problematika muamalah yang terus berkembang dan mengakibatkan terjadinya pergeseran values dalam kehidupan manusia menjadi alasan bagi Al-Qur'an untuk menyediakan prinsip-prinsip umum berkaitan dengan problematika muamalah. ${ }^{34}$

Konstruk hukum yang ada dalam teks Al-Qur'an juga serupa dengan teks yang bersumber dari nabi. Berdasarkan sudut pandang demikian, dapat dipastikan bahwa setiap teks syariah, termasuk hadis, yang menyatakan syarat kepala negara tidak seluruhnya berada pada level yang sama. Para ahli hukum membagi prasyarat tersebut ke dalam kategori, yaitu syarat mutlak dan komplementer (mukammilat). Karena putusan MK mengandung sub kajian fiqh siyasah, sub-pembahasan ini akan mengerucutkan pada dua anasir figh siyasah, yaitu prasyarat Quraisy dan Ijtihad maslạ̣i sebagai bentuk lain dari open legal policy.

1. Hadis Quraisy

Para perawi hadis meriwayatkan hadis Quraisy dalam karya mereka. Di antaranya Imam al-Bukhārì (w. 870), Imam Muslim (w. 875), dan Imam Abū Dāwud (w. 889). Penggalan hadis yang disebutkan alMāwardi ditemukan dalam Musnad Aḥmad Ibn Hạbal (w. 855). ${ }^{35}$ Tema

\footnotetext{
${ }^{33}$ Kaidah menyatakan, al-'ibrah fil-'uqūd lil-maqāsid wal-ma'àni là lil-alfä̌̀ wal-mabānì. Bahwa yang diakui dalam hukum muamalah, termasuk transaksi, ialah tujuan dan substansinya, bukan lafal dan formatnya. Khairuddin Habziz, Kaidah Figh, cet. Ke-3 (Sukorejo: Tanwirul Afkar, 2019), 22.

34 'Abd al-Wahhāb Khalāf, Tlm Ușūl al-fiqh, cet. Ke-7 (T.t.: Maktabat al-Da'wah alIslāmiyyah, 1956). 33-34.

35 Ahmad ibn Muhammad ibn Hanbal, Musnad al-Imam Ạ̣mad Ibn Hanbal, Juz II (Beirut: al-Maktabah al-Islāmi, 1398), 421.
} 
serupa juga ditemukan dalam karya al-Bukhāri, ${ }^{36}$ al-Bayhaqi (w. 1066), ${ }^{37}$

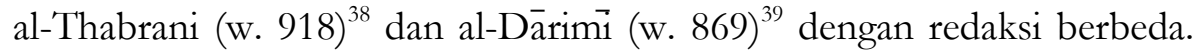
Hadis Quraisy cukup popular dan sering kali ditarik pada kesimpulan bahwa secara tegas Nabi mengajukan prasyarat Quraisy harus dipenuhi calon kepala negara. Pembahasan tentang Quraisy dibahas lebih mendalam oleh Ibn Khaldūn (w. 1406), sejarawan Muslim yang juga dikenal sebagai sosiolog Muslim.

Untuk memahami akar teori Ibn Khaldūn (w. 1406) tentang Quraisy, konstruk pandangannya tentang asal mula terbentuknya negara perlu dijabarkan terlebih dahulu. Ia mencatat sejarah bangsa Arab diwarnai konflik dan penaklukan antar suku, ${ }^{40}$ baik untuk memperebutkan wilayah maupun sumber daya. Karena lazim terjadi peperangan, sekelompok suku Arab mulai membuat kesepakatankesepakatan saling menjaga teritorial dan membuat perjanjian damai. Pada akhirnya, negara Arab dalam pengertian yang sederhana terbentuk tak hanya berdasarkan kesamaan geografis semata, namun karena persamaan darah atau keturunan. Pertalian darah inilah yang kemudian dikenal dengan 'asabiyyah.

Dengan narasi kesejarahan demikian, sangat logis jika kepala negara berasal dari suku terkuat yang mampu mempersatukan antar suku yang ada. Anak keturunan Mudar ibn Nizār yang menjadi cikal bakal lahirnya suku Quraisy, lanjut Ibn Khaldūn, telah lama dikenal sebagai suku penakluk yang dihormati suku lain dan memiliki posisi strategis sehingga dapat meredam terjadinya konflik. Legitimasi Quraisy yang didapat melalui teks syariah, menurut Ibn Khaldūn, secara lebih jauh mampu mengadvokasi misi-misi agama dan mudah mencapai kata mufakat saat mengambil kebijakan politik di hadapan bangsa Arab. Atas dasar itu, Ibn Khaldūn menjelaskan sebab operatif ('illat) disyaratkannya Quraisy adalah untuk menghindari terjadinya pertikaian (raf' al-tanä $\left.\mathbf{u}^{\prime}\right){ }^{41}$

36 Muhammad Ibn Ibrahim al-Bukhārì, Sahịh al-Bukhārì (Beirut: Dār al-Kutub al'Ilmiyyah, 2009), 1293.

${ }_{37}$ Abū Bakr Aḥmad ibn al-Husayn ibn 'Ali al-Bayhaqi, al-Sunan al-Kubrā, vol. 8 (India: Majlis Däirat al-Ma’arif an-Niz̄āmiyyah, 1334 H), 141.

38 Sulaymān ibn Aḥmad ibn Ayyūb Abū al-Qāsim al-Ṭabrāni, al-Mu'jam al-Kabìr (Maushul: Maktabat al-'Ulūm wal-Hikam, 1983 M/ 1404 H), 337.

39 'Abdullāh ibn 'Abdurraḥmān Abū Muhammad al-Dārimi, Sunan al-Dārimì (Beirut: Dār al-Kutub al-Arabi, 1407 H), jil. 2, h. 315.

40 Ibn Khaldūn, Muqaddimah, Juz. 1, tahqiq Abdullah Muhammad al-Darwisy (Damaskus: Dār Ya’rib, 2004), 254.

${ }^{41}$ Ibn Khaldūn, Muqaddimah, 371. 
Al-Jābirì menggarisbawahi pernyataan Ibn Khaldūn tak perlu ditafsirkan secara tekstual. Jika Ibn Khaldūn konsisten dengan 'asabiyyah yang ia konstruk sendiri, suksesor kepala negara berikutnya harus berasal dari klan terkuat setelahnya (al-aqwa min-furüihī), seperti pada kasus Nabi Muhammad Saw. Suksesor setelahnya harus berasal dari klan Hasyimiyah atau Umawiyah, dua klan terkuat Bani Quraisy dan yang paling berhak memegang tampuk kekuasaan. Tampilnya Abu Bakar sebagai khalifah justru yang tak memiliki garis keturunan Hāshimiyyah atau Umawiyyah, akan tetapi berasal dari klan Taymi, secara tidak langsung mematahkan argumen Quraisy. ${ }^{42}$ Dari sini, Quraisy tak lebih merupakan simbol keberanian dan klan terkuat yang dapat dimiliki siapa saja. Platform tersebut ditopang pandangan yang mengkritik hadis Quraisy dalam pengertian garis keturunan pasca dibentuknya konsep negara modern dan tribalisme bangsa Arab yang mulai ditinggalkan. ${ }^{43}$

Perlu diketahui, teori 'asabiyyah Ibn Khaldūn hanya berlaku dalam masyarakat yang menganut sistem pemerintahan primitif seperti yang diadopsi bangsa Arab pra-Islam. Kelemahan teori ini terlihat dari upaya justifikasi atas superioritas bangsa Arab di atas bangsa Non-Arab ('Ajam) berikut konstruk budaya yang secara langsung memengaruhi ajaran dan dogma keagamaan. Meminjam pendapat Elmessiri, ${ }^{44}$ 'asabiyyah yang tetap dipertahankan hanya akan melahirkan friksi Quraisy-Non Quraisy, Arab-Non Arab dan mayoritas vis a vis minoritas. Mayoritas akan menilai diri mereka sebagai komunitas yang paling berhak menduduki jabatan strategis dan menciptakan warga negara kelas dua sehingga kedewasaan berpolitik sulit diwujudkan dalam iklim demokrasi.

Yang penting dipahami, hadis Quraisy menunjukkan akseptabilitas masyarakat yang perlu dimiliki kepala negara dalam bentuk dukungan

\footnotetext{
42 'Ābid al-Jābiri, Fiker 'Tbn Khaldūn: al-'Asabiyyah wal-Mujtama' Ma'alim Naz̧hariyyah Khalduniyyah fit-Tarikh al-Islamiy), cet. Ke-6 (Berikut: Markaz Dirasat al-Wihdah alIslamiyyah, 1994), 204-206.

43 'Abd al-Qādir 'Awdah, al-Islām wa-Awḍ'unā al-Siyasisiyyah (Beirut: Muassasat al-Risālah, 1981), 143-145.

44 Elmessiri mengajukan gagasannya tentang bias epistemologi saat menelaah studi Islam yang dihasilkan sarjanawan Muslim lulusan Barat. Ia mengungkapkan adanya problem metodologi sarjanawan Muslim yang tanpa disadari mengginggapi alam fikiran mereka saat mengkaji Islam, namun turut membawa ideologi Barat yang merasuk ke dalam sendiri-sendiri epistemologi Barat. Selengkapnya, lihat: Abdelwahab M. Elmessiri, et.all., Epistemological Bias in The Psysical and Social Science (Herndon: International Institute of Islamic Thought, 2013). Bias epistemologi juga sesungguhnya terjadi di kalangan Muslim sendiri dalam menyusun doktrin dan sebagian besar ajaran Islam yang terkondifikasi dalam buku-buku klasik. Karenanya, sulit untuk memisahkan ajaran Islam orisinil dan yang terpengaruh budaya Arab.
} 
sosial dan politik. ${ }^{45}$ Interpretasi demikian akan dipahami jika tafsir diarahkan untuk mengurai makna teks berdasarkan kemaslahatan yang dapat ditemukan. ${ }^{46}$ Diyā' al-Dìn Al-Rays menyatakan,

"Hadis itu harus dipahami bahwa penguasa perlu memiliki tingkat akseptabilitas yang tinggi agar mendapat legitimasi masyarakat karena kekuasaannya bersumber dari masyarakat secara langsung. Hadis Quraisy juga menyadarkan pentingnya kewibawaan dimiliki penguasa agar keberadaannya membawa persatuan masyarakat dan mampu menghindari konflik yang terjadi. Tafsir kontekstual atas hadis Quraisy relevan dengan platform masyarakat modern yang bertransformasi dari ikatan-ikatan primordial menuju ikatan sosial dan politik.,"

Simbol Quraisy yang berarti sifat keberanian dan kekuatan inilah yang juga ditegaskan teks syariah bersamaan dengan sifat primer lainnya seperti terlihat dalam tabel berikut.

\begin{tabular}{|c|c|}
\hline $\begin{array}{l}\text { Tujuan di Balik Pemberlakuan Hukum } \\
\text { Syariah (Maqāșid al-sharî'ah) }\end{array}$ & Rujukan Teks \\
\hline $\begin{array}{l}\text { 1) Mendapat dukungan politik, sosial } \\
\text { dan mampu menjalankan amanah; }\end{array}$ & Q.S. Al-Qașaș, 28: 26 \\
\hline 2) Bersikap adil; & Q.S. Al-Nisā, 4: 59 \\
\hline 3) Manajemen konflik yang baik; & Q.S. Āli 'Imrān, 03: 103 \\
\hline $\begin{array}{l}\text { 4) Mendahulukan persatuan umat di atas } \\
\text { kepentingan agama. }\end{array}$ & Q.S. Tāhāa, 20: 94 \\
\hline
\end{tabular}

2. Open Legal Policy sebagai Ijtihad maslạ̣i Suatu Undang-undang Ijtihad maslạ̄i (maqashid-based ijtihad) ditafsirkan sebagai upaya mengkaji, menganalisis dan menemukan tujuan-tujuan di balik

45 Diyā' al-Dīn al-Rays, al-Nazariyyāt al-Siyāsah al-Islämiyyah, cet. Ke-7 (Kairo: Maktabat Dār al-Turāth, t.th), 302-303; Muhamad Sofi Mubarok, Kontroversi Dalil-dalil Kbilafah (Jakarta: Pustaka Harakatuna, 2017), 149-150.

${ }^{46}$ Ḥannān 'Abd al-Karim dan Muḥammad Khālid Manșūr, "al-Tafsìr al-Maṣlaḥ̣i lil-Naṣ

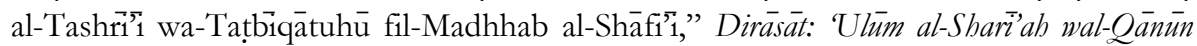
Jilid 43, no. 1 (2016), 394. Istilah lain yang serupa ialah memahami maqāisid al-sharì ah, yaitu memahami nilai-nilai di balik pemberlakuan hukum Syariah melalui teks yang diturunkan/disabdakan. Teori ini banyak dikemukakan para ulama secara detail, misal dalam karya al-Ghazāii (w. 1111) dalam al-Mustasfā min-Tlm al-Ușūl, Abū Ishạà al-Shạtịīi (w. 1388) dalam al-Munāafaqāt fi-Ușūl al-Shari'ah, atau Muhammad Ṭāhir Ibn 'Āshūr (1879 - 1973) melalui karyanya, Maqāsid al-Shari' ab al-Islämiyyah.

47 Diyā' al-Din al-Rays, al-Nazariyyät al-Siyasah al-Islämiyyah, terjemah Abdul Hayyie elKattani, Teori Politik Islam (Jakarta: Gema Insani Press, 2001), 245-246. Lihat juga: Muhamad Sofi Mubarok, Kontroversi Dalil-dalil Khilafah (Jakarta: Pustaka Harkatuna, 2017), 149-150. 
pemberlakuan teks syariah, kemudian mengaplikasikannya terhadap kasus yang hendak dicari ketentuan hukumnya. ${ }^{48}$ Dasar ijtihad model demikian dikembangkan dari ketentuan hukum Islam yang menyatakan seluruh teks syariat memuat nilai kemaslahatan yang inheren di dalamnya. ${ }^{49}$ Objek studi Ijtihad maslạ̣i memiliki cakupan yang sangat luas, tak terkecuali pada aktivisme politik yang seluruhnya bermuara pada terciptanya kemaslahatan rakyat. ${ }^{50}$

Sesungguhnya, rumusan MK terkait open legal policy sangat identik dengan Ijtihad maslaḥi, atau setidaknya quasi-ijtihad. Kesamaan keduanya terletak pada ruang lingkup dan tujuan untuk menjelaskan maksud sekaligus menemukan norma hukum baru dari suatu teks yang dituturkan dengan redaksi global (ijmāt) atau memiliki makna ambigu sehingga terbuka peluang untuk ditafsirkan. Selebihnya, Ijtihad maslạ̣i tidak berlaku pada teks-teks yang memiliki makna lugas (wädịh al-dalälah), berkenaan dengan ritus peribadatan dan dogma agama, serta tidak bertentangan dengan prinsip umum agama. ${ }^{51}$

Sementara, open legal policy dikenal dalam teori hukum konvensional sebagai kewenangan yang diberikan MK terhadap pembentuk undang-undang untuk membuat suatu kebijakan dalam undang-undang sebagai langkah menerjemahkan sekaligus mengimplementasikan norma UUD 1945. Dalam uji materi presidential threshold, open legal policy menjadi pertimbangan hakim MK lantaran UUD

48 Aḥmad al-Raysūnì dan Muhammad Jamāl Bārūt, al-Ijtihād: al-Nașs, al-Wäqi', alMașlaḥah (Beirut: Dār al-Fikr al-Mu'āṣir, 2000), 55.

${ }^{49}$ Salah satu ahli fiqh yang mencetuskan gagasan teks dan maslahat ialah Najm al-Din al-Ṭûfi (w. 1316). Dalam karya kontroversinya, Risālah fi-Ri’àat al-Maṣlaḥah. Saat mengurai kontradiksi yang terjadi antara teks dan maslahat, sering kali maksud al-Ṭüfi ditafsirkan keliru dengan pengagungan nilai kemaslahatan jika terjadi pertentangan antar teks dan maslahat. Padahal, al-Ṭüfi sendiri mengajukan syarat didahulukannya maslahat di atas teks syariah jika teks yang dimaksud masuk dalam domain hukum muamalah, kemaslahatan tersebut bukan dimaksudkan untuk menganulir suatu teks (naskh) dan kemaslahatan tersebut ditempatkan sebagai spesifier dari suatu teks (mukhassis). Selengkapnya, lihat: Najm al-Din al-Ṭufi, Risälah fï-Ri'ayat al-Maslaḥah (Alexandria: alDār al-Mașriyyah al-Lubnāniyyah, 1993).

${ }^{50}$ Kaidah fiqh menyatakan,

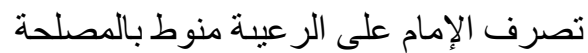

Artinya, kebijakan yang dilakukan pemimpin sangat bergantung pada kemaslahatan rakyat. Redaksi tersebut ditemukan dalam karya Jalāl al-Din al-Suyuthi, al-Ashbāh walNazāir (Beirut: Dār al-Kutub al-'Ilmiyyah, 1983), 121. Bandingkan: 'Abd al-Karim al'Āni, al-Ḍawābit al-Ușüliyyah lil-Ijtihāed fil-Siyāsah al-Shar'iyyah (Beirut: Dār al-Kutub al'Ilmiyyah, 1434H/2013), 223.

51 'Abd al-Wahhāb Khalāf, Tlm Ushul..., 33. 
1945 tidak mengatur hal tersebut secara rinci. Logika hukum demikian dikritisi Abdul Ghoffar dengan menyatakan tidak ada hubungan secara langsung antara presidential threshold dengan stabilitas pemerintahan seperti praktik ketatanegaraan Amerika dan Brazil. ${ }^{52}$

Guna mengantisipasi open legal policy pada perkara perkara presidential threshold, alternatif yang dapat ditempuh adalah menciptakan koalisi permanen antara pasangan calon presiden dan wakil presiden bersama partai pengusungnya untuk menghindari koalisi semu yang didasarkan motif kepentingan pragmatis sesaat. ${ }^{53}$ Cara-cara radikal juga dapat ditempuh dengan dihapuskannya presidential threshold untuk mengembalikan sistem presidensial sebagaimana amanat UUD 1945, membebaskan calon presiden dan wakil presiden dari sandera partai politik, serta memberikan akses merata bagi seluruh partai politik peserta pemilu, baik partai lama maupun partai yang baru terlibat dalam proses pemilihan umum. ${ }^{54}$

Produk yang dihasilkan Ijtihad maslaḩi maupun open legal policy sesungguhnya sama-sama berupaya menciptakan kemaslahatan manusia. Hanya saja, patut ditekankan bahwa pembentuk undang-undang, hakim dan mujtahid merupakan lembaga otoritatif yang kewenangannya didapat secara langsung melalui mandat agama maupun undang-undang. Keduanya juga dituntut untuk mempertanggungjawabkan produk hukumnya sesuai tradisi masing-masing.

Al-Qarā̄î menyatakan, hakim (demikian pula pembuat undangundang) adalah agen sekaligus representasi Tuhan. Artinya, cakrawala ijtihad yang dimiliki seorang hakim menjangkau kekuasaan untuk mengkreasi atau membatalkan suatu hukum. Posisi hakim, lanjut alQarāfi, jauh lebih tinggi dibanding seorang mufti yang hanya diberi wewenang untuk menafsir dan menjelaskan maksud teks syariah apa adanya tanpa perubahan. ${ }^{55}$ Melalui Ijtihad maslạ̣i inilah hakim dituntut untuk menggali nilai kemaslahatan meskipun di satu sisi tidak menguasai piranti ijtihad sesuai mekanisme ijtihad fiqh. ${ }^{56}$

\footnotetext{
52 Abdul Ghaffar, "Problematika Presidential Threshold: Putusan Mahkamah Konstitusi dan Pengalaman di Negara Lain," Jurnal Konstitusi 15, No. 3 (September 2018), 498.

${ }^{53}$ Lutfil Ansori, "Telaah terhadap Presidential Threshold dalam Pemilu Serentak 2019," Jurnal Yuridis Vol. 4 No. 1 (Juni, 2017), 15-27.

54 Rahmat Teguh Santoso Gobel, "Rekonseptualisasi Ambang Batas Pencalonan Presiden dan Wakil Presiden (Presidential Threshold) Dalam Pemilu Serentak," JALREV: Jambura Law Review 1, no. 01 (2019), 115-117.

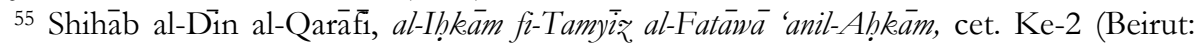
Dār al-Basyair al-Islamiyyah, 1995), 43-44.

${ }^{56}$ Shihāb al-Dìn al-Qarāî̀, al-Iḥkēam..., 53-56.
} 
Namun demikian, baik Ijtihad maslặi maupun open legal policy tetap memiliki kelemahan pada beberapa aspek. Iwan Satriawan menilai, penetapan open legal policy yang dimaksud MK melaui dua putusan di atas memunculkan standar ganda bagi pembentuk undang-undang. MK menetapkan wewenang yang luar biasa bagi pembentuk undang-undang untuk merumuskan norma dan kebijakan dalam menafsirkan serta mengimplementasikan undang-undang, namun akan berbahaya jika pembentuk undang-undang bertindak sewenang-wenang dalam menentukan materi dan bagaimana materi tersebut akan diatur. ${ }^{5}$

Sikap otoriter pembuat fatwa keagamaan ini pula yang mendapat kritik tajam Khaled M. Abou el-Fadl, terutama menyikapi fatwa yang dikeluarkan CLRO (Council for Scientific Research and Legal Opinion, lembaga yang diberi kepercayaan mengeluarkan fatwa di Arab Saudi) yang cenderung otoriter sekaligus 'memaksakan' tafsir yang mengakibatkan terjadinya monisme hukum, alih-alih menjadi sumber rujukan otoritatif bagi Muslim yang menempatkan fiqh sebagai produk hukum yang bersifat dugaan (zann) sehingga memungkinkan terjadinya perbedaan pandangan di kalangan ahli hukum Islam. ${ }^{58}$ Untuk membendung sikap otoritarianisme pembuat hukum dan undang-undang, baik sebagai ekses diberlakukannya open legal policy maupun Ijtihad maslạ̣i, Khaled M. Abou el-Fadl menawarkan lima diktum agar putusan hukum apapun yang dihasilkan terhindar dari sikap otoriter dan dapat dipertanggungjawabkan. Lima diktum tersebut adalah:

\footnotetext{
${ }^{57}$ Iwan Satriawan dan Tanto Lailam menguji argumentasi open legal policy sebagaimana dipertimbangkan MK pada dua kasus yang dijadikan sampel, yaitu ketentuan presidential threshold dan perluasan makna zina. Dari kedua kasus tersebut ditemukan fakta bahwa MK gagal meletakkan garis demarkasi yang jelas dalam kapasitasnya sebagai negative sekaligus positive legislator. Kekacauan penggunaan dua fungsi tersebut juga mengakibatkan MK sulit memosisikan keberpihakannya terhadap judicial activism dan judicial restraints secara proporsional dan konsisten. Sebagai contoh, dalam kasus gugatan presidential threshold, semestinya MK perlu mempertimbangkan fakta bahwa telah terjadi kompromi politik yang terjadi antara capres -cawapres dan partai pengusungnya yang mengakibatkan presiden terpilih akan tersandera partai pengusung. Seharusnya MK melakukan keberpihakan terhadap judicial activism dengan tetap memberikan kesempatan yang sama bagi partai lama maupun partai yang baru berpartisipasi dalam pemilu untuk memperkuat sistem presidensial, sehingga kesan presidensial rasa parlementer dapat dihindari dengan mengabulkan gugatan uji materi tentang UU Pemilu, terutama Pasal 222. Selengkapnya, Iwan Satriawan dan Tanto Lailam, "Open Legal Policy dalam Putusan Mahkamah Konstitusi dan Pembentukan Undang-Undang," Jurnal Konstitusi 16, no, 3 (September 2019), 559-584.

${ }^{58}$ Khaled M. Abou el-Fadl, Atas Nama Tuhan: Dari Fikih Otoriter ke Fikih Otoritatif, terj. R. Cecep Lukman Yasin (Jakarta: PT. Serambi Ilmu Semesta, 2004)246-258.
} 
1) Kejujuran (bonesty). Kejujuran yang dimaksud di sini ialah kejujuran terhadap keterbatasan seorang ahli hukum dalam memahami maksud dari titah agama (al-nushush al-syarizyyab). Kejujuran juga dimaksudkan untuk mengungkap seluruh titah Tuhan sebagaimana adanya tanpa upaya menutup-nutupi.

2) Ketekunan (diligence). Ketekunan ditafsirkan sebagai usaha logis untuk meneliti, menemukan serta memahami serangkaian titah Tuhan yang relevan dengan persoalan tertentu. Dalam mengurai suatu persoalan, seorang ahli hukum tidak boleh menggunakan standar umum yang berlaku dalam masyarakat untuk menyelidiki teks syariah secara taklid, akan tetapi harus menggunakan standar ilmiah yang dapat dipertanggungjawabkan, karena aktivitas ijtihad merupakan instrumen keagamaan yang kelak akan dimintai pertanggungjawabannya di hadapan Tuhan karena berkaitan dengan keselamatan manusia.

3) Kemenyeluruhan (comprehensiveness). Maksud dari poin ketiga ini ialah seorang ahli hukum harus menyelidiki seluruh teks yang relevan secara holistik dengan topik yang hendak diselesaikan. Di sini harus dipahami bahwa suatu teks saling terkait satu sama lain, sehingga suatu teks bukanlah entitas yang berdiri sendiri (interkoneksitas teks).

4) Mendasarkan pendapatnya pada argumentasi logis (reasonableness). Poin keempat ini ditafsirkan sebagai upaya menafsirkan teks syariah dengan rasionalitas. Dalam menafsirkan teks, seorang ahli hukum harus mempertimbangkan apakah tafsir yang ia produksi relevan dengan konstruksi masyarakat yang berlaku. Dengan kata lain, ia harus menyadari bahwa makna dibangun di dalam komunitas atau masyarakat. Mengaitkan teks pada konteks di mana masyarakat hidup dan berkembang harus dilakukan seorang penafsir. Dalam konteks demikian, ia dilarang memaksakan suatu tafsir atas suatu teks yang menyuguhkan kehendak pembaca dibandingkan makna asli dari teks itu sendiri. Ia juga harus menghindari kesewenangwenangan terhadap teks dengan menutup adanya kemungkinan tafsir makna lainnya yang terkandung dalam sebuah teks dengan mengatakan bahwa teks tersebut hanya memuat satu makna yang rigid.

5) Pengendalian diri (self-restraint). Pengendalian diri merupakan bentuk kesadaran yang harus dimiliki seorang penafsir dengan penuh kerendahhatian bahwa hanya Tuhan yang paling mengetahui maksud dari suatu teks. Sikap demikian penting untuk memberikan garis demarkasi antara kewenangan menafsirkan dengan merebut 'posisi' dan otoritas Tuhan, kemampuan untuk menahan diri berbicara pada 
hal-hal yang tidak ia ketahui serta tidak menghukumi sesuatu jika ia gagal menemukan bukti yang cukup untuk menyelesaikan suatu kasus. ${ }^{59}$

\section{Penutup}

Islam secara tegas menyatakan bahwa penguasa mendapatkan mandat untuk mengatur jalannya pemerintahan karena dipilih oleh dan untuk rakyat. Karenanya, pemaknaan hadis Quraisy secara substantif yang mengandung arti bahwa ia harus berasal dan didukung oleh klan atau suku terkuat di wilayahnya logis dijadikan argumentasi guna menciptakan stabilitas pemerintahan. Hal tersebut juga sejalan dengan dalil yang diajukan Mahkamah Konstitusi melalui putusannya dalam menetapkan presidential threshold tidak bertentangan dengan UUD 1945 karena kompromi politik merupakan hal yang tak bisa dihindari sebagai dinamika yang terjadi dalam proses menjalankan demokrasi, sepanjang dimaksudkan untuk menciptakan stabilitas pemerintahan dan tidak bertentangan dengan norma UUD 1945.

Namun demikian, para pembentuk undang-undang maupun fatwa keagamaan harus konsisten berpijak pada upaya menciptakan kemaslahatan umum, alih-alih terjebak pada kepentingan pragmatis sesaat. Sikap otoriter juga perlu dihindari dengan memegang teguh lima diktum yang dikemukakan Khaled M. Abou el Fadl, berupa kejujuran (bonesty), ketekunan (diligence), kemenyeluruhan (comprehensiveness), mendasarkan pada argumentasi logis (reasonableness) dan pengendalian diri (self-restraint). Wallahu a'lam.]

${ }^{59}$ Khaled M. Abou el-Fadl, Speaking in God's Name: Islamic Law, Authority and Women (London: OneWorld Publcation, 1st Edition, 2001), 116-120. Lihat juga: Muhammad Lutfi Hakim, "Hermeneutik-Negosiasi dalam Studi Fatwa-fatwa Keagamaan: Analisis Kritik terhadap Pemikiran Khaled M. Abou el Fadl," Istinbath: Jurnal Hukum dan Ekonomi Islam 19, no. 1 (2020), 27-52. 


\section{Daftar Pustaka}

'Asymawi, Sa'id, al-Khiläfah al-Islämiyyah, vol. II. Kairo: Sina lil-Nasyr, cet. Ke-2, 1992.

'Awdah, 'Abd al-Qādir. al-Islām wa-Awda'unā al-Siyasizyyah. Beirut: Muassasat al-Risālah, 1981.

Ahmad, Muhammad Hazim. "Book Review: Ali bin Muhammad AlMāwardi, 2006, Al-Ahkam As-Sulthaniyyah, Tahkik: Ahmad Jad, 1 Jilid, 336 halaman," 'Ulum Islamiyyab: The Malaysian Journal of Islamic Sciences 23 (April, 2018).

Al-'Āni, 'Abd al-Karim. al-Ḍawābit al-Ușüliyyah lil-Ijtibād fil-Siyāsah alShariyyah. Beirut: Dār al-Kutub al-'Tlmiyyah, 1434H/2013.

Al-'Arabi, Muhammad Mamdūh. Dawlat al-Rasūl fil-Madinah. T.t.: alHay'ah al-Mișriyyah al-'Ā'mmah lil-Kitāb, 1988.

Al-Bayhaqì, Abū Bakr Aḥmad ibn al-Husayn ibn 'Ali. al-Sunan al-Kubrā, vol. 8. India: Majlis Däirat al-Ma'arif an-Nizāmiyyah, $1334 \mathrm{H}$.

Al-Bukhāri, Muhammad Ibn Ibrāhim. Șaḥị̧ al-Bukhärì. Beirut: Dār alKutub al-'Ilmiyyah, 2009.

Al-Dārimi,Abdullah ibn 'Abdurraḥmān Abū Muhammad. Sunan alDärimi. Beirut: Dār al-Kutub al-'Arabi, 1407 H.

Al-Ghazāīi, Abū Hạmid. Al-Mustasfā min Tlm al-Ușūl, vol. 1. Beirut: Muassasat al-Risālah, 1997. . Ibyā Ulum ad-Dīn. Beirut: Dār Ibn Hazm, 2006.

Al-Jābiri, 'Ābid. Fiker 'Ibn Khaldūn: al-'Asabiyyah wal-Mujtama' Ma'alim Naz̧ariyyah Khaldūiyyah fil-Tärikh al-Islami), cet. Ke-6. Berikut: Markaz Dirāsāt al-Wiḥdah al-Islāmiyyah, 1994.

Al-Karim, Hannān 'Abd dan Muhammad Khālid Manșūr. "al-Tafsir alMaṣlaḥi lil-Naṣ al-Tashrīi wa-Tațīiātuhū fil-Madhhab al-

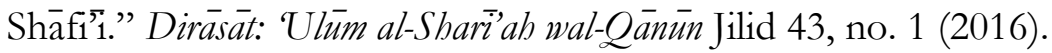

Al-Māwardi, Abu al-Hasan. al-Aḥkām al-Sultaniyyah. Kuwait: Maktabat Dār Ibn Qutaybah, 1989.

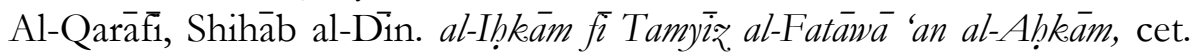
Ke-2. Beirut: Dār al-Bashāir al-Islāmiyyah, 1995.

Al-Rays, Diyā' al-Dīn. al-Nažariyyāt al-Siyāsah al-Islamiyyah, cet. Ke-7. Kairo: Maktabat Dār al-Turāth, t.th.

Al-Raysuni Ahmad dan Muḥammad Jamāl Bārūt. Al-Ijtihäd: al-Naṣs, alWäqi', al-Maslahah. Beirut: Dār al-Fikr al-Mu'ashir, 2000.

Al-suyūtịi, Jalāl al-Dìn. al-Ashbāh wal-Naz̧äir. Beirut: Dār al-Kutub al'Ilmiyyah, 1983. 
Al-Ṭabrānī, Sulaymān ibn Aḥmad ibn Ayyūb Abū al-Qāsim. al-Mu'jam alKabir. Maushul: Maktabat al-'Ulūm wal-Hikam, 1983 M/ 1404 H.

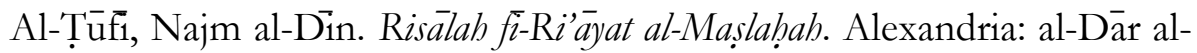
Mașriyyah al-Lubnāniyyah, 1993.

Al-Zirkili, Khairuddin bin Mahmud. al-A'lam, cet. Ke-15, vol. 1. Tt: Dār al-'Tlm lil Malāyin, 2002.

Al-Zuhayli, Wahbah. al-Fiqh al-Islamī wa Adillatubū, cet. Ke-12, vol. 8. Damaskus: Dār al-Fikr, tth.

Ansori, Lutfil. "Telaah terhadap Presidential Threshold dalam Pemilu Serentak 2019." Jurnal Yuridis Vol. 4 No. 1 (Juni, 2017).

Aziz, Samsudin. "Kanunisasi Fikih Jinayat Kontemporer: Studi Materi Muatan Qanun Jinayat Aceh dan Brunei Darussalam." Al-Abkam: Jurnal Pemikiran Hukum Islam, Vol. 24, No. 2 (2014).

Denisatria, Mohammad Fandi, S.H., "Mahkamah Konstitusi sebagai Negative Legislator dan Positive Legislator," sumber: https://www.hukumonline.com/klinik/detail/ulasan/lt5c062fbc 83162/mahkamah-konstitusi-sebagai-inegative-legislator-i-danipositive-legislator-i. Diakses: 09/11/2020, Pkl. 22.12 WIB.

El-Fadl, Khaled M. Abou. Atas Nama Tuhan: Dari Fikih Otoriter ke Fikih Otoritatif, terj. R. Cecep Lukman Yasin. Jakarta: PT. Serambi Ilmu Semesta, 2004.

Speaking in God's Name: Islamic Law, Authority and Women. London: OneWorld Publcation, 1st Edition, 2001.

Elmessiri, Abdelwahab M. et.all. Epistemological Bias in The Psysical and Social Science. Herndon: International Institute of Islamic Thought, 2013.

Fahmi, Khairul. "Nilai-nilai Filosofi Putusan Mahkamah Konstitusi yang Final dan Mengikat." Jurnal Konstitusi, Vol. 7, No. 3 (2010).

Ghaffar, Abdul. "Problematika Presidential Threshold: Putusan Mahkamah Konstitusi dan Pengalaman di Negara Lain." Jurnal Konstitusi 15, No. 3 (September 2018).

Gobel, Rahmat Teguh Santoso. "Rekonseptualisasi Ambang Batas Pencalonan Presiden dan Wakil Presiden (Presidential Threshold) dalam Pemilu Serentak." JALREV: Jambura Law Review 1, no. 01 (2019).

Habziz, Khairuddin. Kaidah Fiqh, cet. Ke-3. Sukorejo: Tanwirul Afkar, 2019.

Hakim, Muhammad Lutfi. "Hermeneutik-Negosiasi dalam Studi Fatwafatwa Keagamaan: Analisis Kritik terhadap Pemikiran Khaled M. Abou el Fadl." Istinbath: Jurnal Hukum dan Ekonomi Islam 19, no. 1 (2020). 
Heyns, Christof. "Introduction to Socio-Economic Rights in The South African Constitution [Part 1]", 2, t.th, dalam Maruarar Siahaan, "Peran Mahkamah Konstitusi dalam Penegakan Hukum Konstitusi", Jurnal Hukum, Vol. 16, No. 3 (2009).

Ibn Ḥanbal, Aḥmad ibn Muḥammad. Musnad al-Imām Aḥmad Ibn Hanbal, Juz II. Beirut: al-Maktabah al-Islāmi, 1398.

Ibn Hazm. al-Ṭuru al-Hukmiyyah fil-Siyasah al-Syar'iyyah, tahqiq 'Ișām

Farris al-Ḥarastāni dan Hịsān Abd al-Manān. Beirut: Dār al-Jìl, 1998.

Ibn Khaldūn. Muqaddimah, Juz. 1, tahqiq Abdullah Muhammad alDarwisy. Damaskus: Dār Ya'rib, 2004.

Jum'ah, 'Ali. 'Im Ușül al-fiqh wa 'Alāqatubū bil-Falsafah al-Islämiyyah. Kairo: al-Ma'had al-'Ālami lil-Fikr al-Islāmi, 1996.

Kamali, Mohammad Hashim. "Issues in the Legal Theory of Usul and Prospects for Reform." Journal of Islamic Studies,Vol. 40, No. 1 (2001).

Khalāf, "Abd al-Wahhāb. Tlm Ușū al-fiqh, cet. Ke-7. T.t.: Maktabat alDa'wah al-Islamiyah, 1956.

Kuwait: Dār al-Qalam, 1985.

Mas'ud, Muhammad Khalid. "Application of Islamic Law in Courts." ISIM, Vol. 9, No. 2 (2006).

Mubarok, Muhamad Sofi. Kontroversi Dalil-dalil Khilafah. Jakarta: Pustaka Harakatuna, 2017.

Mudzhar, M. Atho. "Tantangan Studi Hukum Islam di Indonesia Dewasa Ini," Indo-Islamika 2, No. 1 (2012/1433).

Munfarida, Elya. "Analisis Wacana Kritis dalam Perspektif Norman Fairclough," Komunika 8, No. 1 (Januari - Juni, 2014).

Nurhardianto, Fajar. "Sistem Hukum dan Posisi Hukum Indonesia." Jurnal TAPIs 11, No. 1 (2015).

Salim, Arskal Salim dan Azyumardi Azra. "Introduction: The State and Sharia in the Perspective of Indonesian Legal Politics", dalam Arskal Salim dan Azyumardi Azra, (ed.), Sharia and Politics in Modern Indonesia. Singapura: Institute of Southeast Asia Studies, 2003.

Satriawan, Iwan dan Tanto Lailam. "Open Legal Policy dalam Putusan Mahkamah Konstitusi dan Pembentukan Undang-Undang." Jurnal Konstitusi 16, no, 3 (September 2019).

Sofyan, Syafran. "Putusan Mahkamah Konstitusi Tentang Status Anak Luar Kawin”, www.jimlyschool.com (diakses 21/02/2014). 
Zubaida, Sami. Law and Power in The Islamic World. New York: I.B. Tauris \& Co. Ltd, 2005.

Peraturan Perundang-undangan

Undang-Undang Nomor 8 Tahun 2011 tentang Perubahan Atas Undang-Undang Nomor 24 Tahun 2003 tentang Mahkamah Konstitusi.

Undang-undang Nomor 7 Tahun 2017 tentang Pemilihan Umum.

Putusan Mahkamah Konstitusi Nomor 53/PUU-XV/2017 tentang Pengujian UU Nomor 7 Tahun 2017 tentang Pemilihan Umum.

Putusan Mahkamah Konstitusi Nomor 48/PUU-IX/2011. 